\title{
Organisations beyond Brundtland: A Definition of Corporate Sustainability Based on Corporate Values
}

\author{
Jan Thomas Frecè ${ }^{1} \&$ Deane L Harder ${ }^{1}$ \\ ${ }^{1}$ Bern University of Applied Sciences, Switzerland \\ Correspondence: Jan Thomas Frecè, Bern University of Applied Sciences, Switzerland. E-mail: \\ jan.frece@bfh.ch
}

Received: July 16, 2018

Accepted: August 14, $2018 \quad$ Online Published: September 28, 2018

doi:10.5539/jsd.v11n5p184

URL: https://doi.org/10.5539/jsd.v11n5p184

\begin{abstract}
Although a plethora of alternatives exist, companies often base their sustainability efforts more or less explicitly on the definition of the Brundtland Commission. There are, however, conceptual problems when this definition is removed from its original context, in which it addresses social policies and state institutions. In particular the notions of "needs of the present" and "future generations" reveal the qualitative differences between the socio-political context of the Brundtland Commission and the corporate context. In this paper, we explore the entailing dilemmas, argue why current approaches to solve them are insufficient and analyse common practices for sustainability-related statements of 50 companies in Switzerland. The results support the argument that companies tend to avoid a specific definition of corporate sustainability or transpose the Brundtland definition, instead. Both approaches are inappropriate as guiding principles for corporate policy. Instead, we propose basing the concept of sustainability on the broad premise that "the future is a better, healthier place than the present", specified and substantiated using functionally formulated corporate values. These corporate values and the vision of a "better place" derived from them gear corporate sustainability efforts towards restitution and/or compensation.
\end{abstract}

Keywords: Brundtland Commission, corporate sustainability, corporate values, future generations, needs of the present, sustainable development, value-based sustainability

\section{Introduction}

If you ask a group of managers from a range of large companies about corporate sustainability, chances are that you will be greeted by a chorus of claims that this is a vitally important topic for their businesses. When you then try to dig deeper and ask what exactly they mean by corporate sustainability, you will probably get a lot of hand-waving and few concrete explanations. The definition of corporate sustainability is as nebulous as the carbon dioxide swirling around our planet. Still, the phrase corporate sustainability can be heard in boardrooms and meetings throughout the business world, with many companies declaring that their operations adhere to its principles. Their actions can be grouped into three categories: sustainable acts (random or lacking a comprehensive framework for guiding efforts), acting in line with sustainability (having a framework for guiding efforts but not necessary in line with overall business activity) and contributing to company specific sustainable development (using a framework for guiding efforts, which are aligned with corporate values). Following the idea that "individual organizations cannot become sustainable: Individual organizations simply contribute to the large system in which sustainability may or may not be achieved" (Jennings \& Zandbergen, 1995), this paper argues that corporate sustainability should contribute to a global sustainable development but can only, and hence should only, set guiding principles for their domains of corporate activity.

Many companies base their sustainability efforts on the conclusions of the Brundtland Commission report (World Commission on Environment and Development, 1987), which defines sustainable development as "[...] development that meets the needs of the present without compromising the ability of future generations to meet their own needs". The mentioned "needs" are commonly interpreted as human needs of present and future generations (Keeble, 1988). Transposing this definition from a socio-political context to a corporate context, however, reveals its inappropriateness for businesses. Moreover, companies' sustainable development activities are subsequently not based on a sound theoretical foundation, or, to look at it another way, the concept of sustainable development in a corporate context becomes somewhat arbitrary. This article sets out to explore this 
definitional and conceptual gap. To this avail, 50 publicly accessible documents published by Swiss companies were analysed for the presence or absence of a definition of corporate sustainability. To align the definition of sustainable development and the role of the corporate sector more consistently, we propose defining organisational sustainability based on organisational values rather than transposed human needs and gearing efforts towards restitution and/or compensation.

\section{Theoretical Considerations}

There is a gap in the definition of corporate sustainability. It could be argued that this gap is of little practical importance as long as companies strive to improve the status quo. However, lacking a sound definition of a "better place" to improve towards, guiding principles for sustainability will remain vague, resulting in a tenuous fit with business initiatives and no cohesive measurement system (Smith \& Sharicz, 2011). With this vagueness in guiding principles, many decision-makers will resort to more readily available financial guiding principles, which have a long tradition of consideration, well defined indicators and a cohesive measurement system applicable to individual companies as well as across whole industries and economies. Subsequently, as financial sustainability is strengthened, the focus on social and environment implications of corporate decisions becomes less prominent. A hands-on definition of corporate sustainability might help to break this negative reinforcing cycle (Figure 1). To provide a theoretical foundation of corporate sustainability, we will first examine some common approaches to sustainability, followed by our proposition for corporate sustainability and an explanation why efforts in corporate sustainability should be geared towards restitution and/or compensation. At the end of this section, we will suggest a systemic model, which illustrates the effect of having a definition of corporate sustainability.

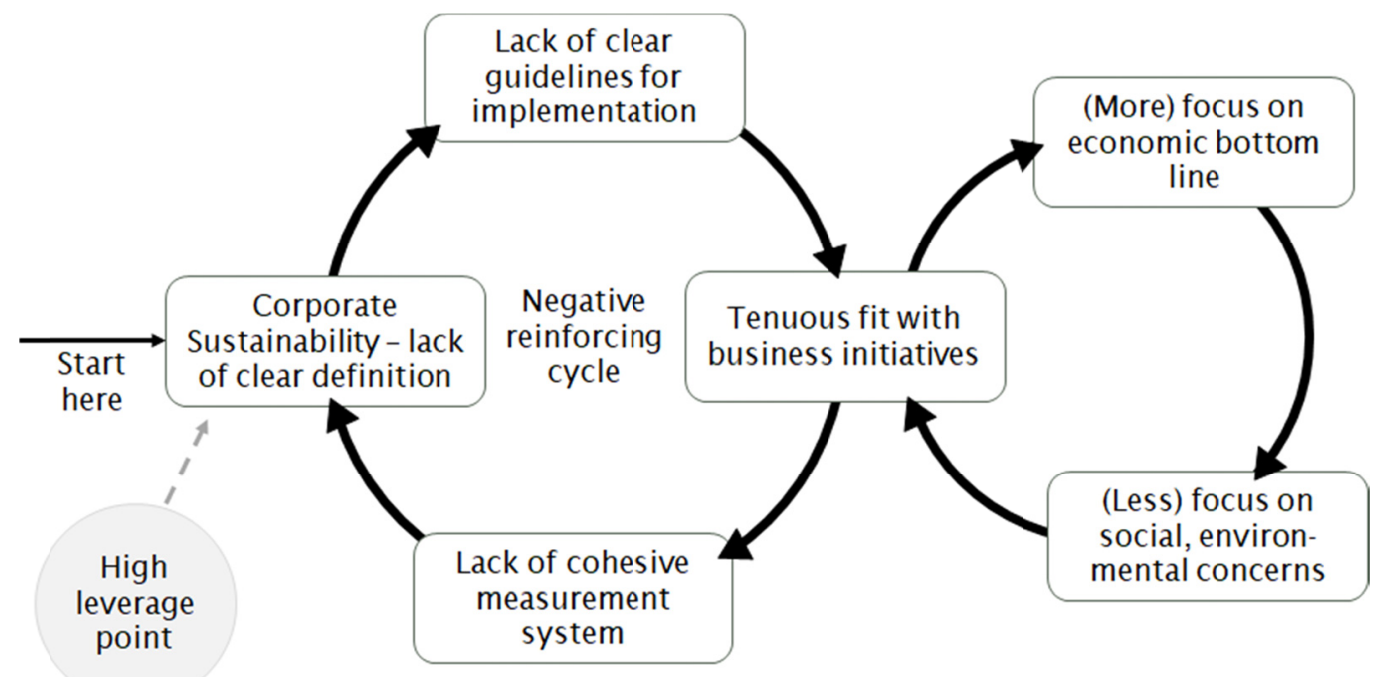

Figure 1. Model of a collective current interpretation of corporate sustainability (adapted from Smith \& Sharicz, 2011)

\subsection{Common Approaches}

The United Nations adopted its Agenda 2030 and the associated 17 Sustainable Development Goals (SDG) in 2016 (United Nations, 2016). At the core of the SDG is the integration of economic, social and ecological concerns in decision-making (Kanie \& Biermann, 2017). The goals address specific areas and issues in sustainable development, which should be achieved by 2030 . The theoretical basis is not made explicit but can be assumed to follow the original Brundtland definition (Emas, 2015), since the wording of the key principle is almost identical (United Nations 2016a). Thus, by adopting the SDG, the UN is at least implicitly adhering to the original definition of sustainable development; an observation, which can be extended to any company referring to SDG as guidelines for their efforts in the field of sustainability. The main target group of the SDG, however, are public policy-makers, rather than corporate decision-makers. Still, for a lot of companies, the SDG are close enough to the core of their efforts in corporate sustainability.

Reporting sustainability of public and often state-run organisations came to prominence in the 1980s. It became quickly apparent that the definition of "needs" of the original definition of sustainable development was too generic as it was not specified if these refer to current needs or future needs of generations to come (Kiss, 2011; 
Stagl \& O'Hara, 2001). Consequently, companies' definitions of corporate sustainability demonstrate a broad range and heterogeneity (Bañon Gomis, A. J., Guillén Parra, M., Hoffman, W. M., \& Mcnulty, 2011; Blewitt, 2015; Hopwood, Mellor, \& O'Brien, 2005; Kiss, 2011; Marshall \& Toffel, 2005). As this article does not intend to propose a new definition of sustainable development, our argumentation will be founded on the original definition by the Brundtland Commission.

This definition is used by many companies, either explicitly or implicitly when referring to the three-pillar model of sustainability or the SDG. If the Brundtland definition is to be used by companies, it requires some adaptation before it can be used as a guiding principle. One such definition might be:

"Sustainable corporate development meets the corporate needs of the present without compromising the ability of future generations of corporations to meet their own needs."

The thought that a company might forfeit the fulfilment of "needs of the present" to allow for the potential of future generation of companies appears impractical, as companies must be considered organizational agents. As such, they do not act in an altruistic parental manner caring for offspring or filial generations and thus any concept of intergenerational equity remains hazy. When transposing the Brundtland definition of sustainable development to the corporate context, the notion of "needs" is probably best ascribed to the developmental path of a company, that is, the future version of the same company or succeeding companies that evolve from the original one through mergers or a re-structuring of the business model. While this idea might be in line with Friedman's (1970) position on the social responsibility of a company and also with the definition of sustainable development of the Dow Jones Sustainability Index (2014), it is in stark contrast to other concepts of sustainable development that define generated benefit more broadly (Marshall \& Toffel, 2005). If applied in isolation, a company acting on this definition of sustainable development would skew the classic three pillar model of sustainability towards the economic pillar, over-emphasising its importance. The ecological and social pillars would be beyond the specific interest of the company and could thus be counted as part of the context rather than part of the organisational system of the company; a scenario that is often described by critics of the model of weak sustainability (Neumayer, 2003). A too literal transposition of the Brundtland definition of sustainable development basically sets the focus of activity on generating profit to maximise the likelihood of corporate survival. If the definition of sustainable development should integrate with an overall societal concept of sustainability, companies are expected to demonstrate ethical behaviour that might interfere with their core economic interest of generating or maximising profit. To integrate these potentially conflicting demands, companies can simply append ethical motivation to the prevalent driver of profit generation. Alternatively, a more elaborate approach can be taken with the Triple Bottom Line (3BL), which uses a slightly different concept but arrives at a similar conclusion, that is a "good old-fashioned single bottom line plus vague commitments to social and environmental concerns" (Norman \& MacDonald, 2004). Although theoretically justifiable, the practical implications prevent this definition from acting as a guiding principle for sustainable corporate activities.

To provide a guiding principle for sustainable activities in a broader sense, the ideas of "future generations" and "needs of the present" typically undergo a reinterpretation in their transposition. While "future generations" is still concerned with humans rather than to-be-founded companies, the "needs of the present" refer to the needs of the company. It cannot refer to the needs of individual humans as this would not entail any kind of activity for the vast majority of companies as their value propositions are not aimed at meeting humanity's urgent needs. The term "generation" can be applied to humans as well as to companies in a figurative sense. Nonetheless, two aspects counteract an interpretation addressing purely future company incarnations. On the one hand, the term "sustainable" is commonly associated with justice and more generally, with long-term welfare (Kiss, 2011); this would prohibit a sole consideration of monetary interests typical for many companies. On the other hand, the second part of the Brundtland definition clearly states that "... the concept of 'needs' [means], in particular the essential needs of the world's poor, to which overriding priority should be given" (World Commission on Environment and Development, 1987, p. Ch IV). It can be safely assumed that the expression "the world's poor" is meant to signify underprivileged humans rather than undercapitalised companies. Overall, the literal words as well as the given context clearly indicate that "generations" describe humans and their needs, also when used by companies. The transposition of the concept of sustainable development thus happens only partially when moved from a socio-political context to a corporate context.

Sticking to the Brundtland definition, the corporate "needs of the present" have to be aligned with the "needs of the poor future human generations". Although sufficiently pragmatic and hands-on, such an approach will be hardly acceptable for most companies and without alignment, corporate activities in the field of sustainability will remain inconsistent. Companies basing their sustainability efforts on the Brundtland definition are 
conceptually caught between a rock and a hard place. Either, companies will only be considered sustainable if they accept the fulfilment of the current and future needs of the poor as fundamental licence to operate, or sustainable development is skewed towards economic interests. Oblivious of this conceptual conundrum, companies face the risk that corporate sustainable will "become everything to everyone" (Smith \& Farley, 2013). What is missing is a practical, activity-oriented definition of corporate sustainability that can act as a guiding principle for general corporate policy without getting immediately lost in detailed indicator definitions or having to fall back to commonplace project templates or marketing-driven initiatives. We will therefore propose such a definition in the following section, based on "socially functional corporate values" (Frecè, 2018) and framing activities as restitutive acts and/or compensation.

\subsection{Corporate Sustainability as Value-Based Concept}

From a neoclassical background, Pareto efficiency is a key argument that should be part of the definition of sustainable development, sometimes limited to a 'potential Pareto efficiency' (Stavins, Wagner, \& Wagner, 2003) It might be, however, too normative with its strong no harm principle and could be replaced by approaches with a weak no harm principle based on evolutionary economics, which considers more dynamic efficiency gains (van Staveren \& others, 2012). Although more realistic in its assumptions, the operationalisation of this evolutionary notion remains difficult as the "no harm" criterion may not be assessed within useful time and with restricted decision making available to individual companies. Additionally, the spatio-temporal boundaries of these considerations are blurry. Thus, orientation towards efficiency provides a thorough theoretical base, but it is less suitable as a guiding principle for corporate sustainability policies precisely because of its idealistic nature.

Companies want to use a definition of corporate sustainability that is practical and suits their specific circumstances without being too generic or arbitrary. The definition we propose is solely based on socially functional corporate values, building on the simple premise that "the future is a better, healthier place than the present" (Blewitt 2008:ix). The specific operationalization of what is considered "better" or "healthier" is dependent on the values and perception of individual stakeholders (Christen, 2010).

The UN Millennium Declaration (United Nations, 2000), for example, emphasises values such a freedom, equality, solidarity, tolerance, respect for nature and shared responsibility, and monitors suitable indicators and goals for a sustainable development. If the emphasis had been on other values, say, sustenance, securing prosperity, personal responsibility, social stability or fair use of natural resources, sustainable development would have a different notion with fundamentally different consequences. Although the outcome might look superficially similarly, basing the definition of sustainable development on specific values makes this approach suitable as a guiding principle for sustainability policies rather than the common ex post rationalisation of many corporate efforts. Hence, basing corporate sustainability efforts on corporate values seems a safe way to proceed.

There is a major caveat if the definition of sustainable development or corporate sustainability is solely based on values. Some corporate decision-makers might cherry-pick values to generate a favourable definition. To counteract this, it could be concluded that "the basic concept of sustainable development requires values which relate to our material and natural conditions and are universally applicable and generally of relevance" (Christen, 2008). At first glance, using this prerequisite can be deemed sufficient. Values are thus chosen to address the greater good and are potentially concrete enough to act as a guiding principle for sustainability policies. If a definition of corporate sustainability is based on such values, however, there are implications that are less prominent than those of the original Brundtland definition but pose a problem for corporate sustainability.

Every company is unique. The claim that corporate values are inextricably intertwined with the material and natural contexts of their stakeholders should be part of the corporate identity that a company might publicly express. Thus, the corporate identity should align with its value proposition and with the value system of its key stakeholders. The expression of corporate identity is in turn the means through which staff may identify corporate behaviour and values. As staff members are the agents of corporate activities and therefore also corporate sustainability, linking corporate values to local circumstances seems appropriate. As the diversity of companies, stakeholders and value chains is conceptually unlimited, restricting values to universal ones for the definition of corporate sustainability would neither reflect companies in their individuality nor provide normative guidance on corporate behaviour or for staff. As corporate values are not ideological but purely functional although relating to human values - and are aimed at communicating the uniqueness and specific character of a company, using universal values would degrade the ability to communicate corporate individuality and corporate values would lose their function. This notion is therefore incompatible with the argument that companies should base their corporate sustainability on values that are universally valid and relevant. Consequently, basing 
corporate sustainability on values is advisable, but using universal values might not solve current issues.

Basing corporate sustainability on company-specific values might render the definition somewhat arbitrary. It could be argued that a company can use this approach as a "carte blanche" to label everything as "sustainable" that appears so from their own perspective. This argument can be counteracted by linking corporate sustainability to a more general model of sustainable development. Common models are the three-pillar model of sustainability (Adams, 2006; Bañon Gomis et al., 2011; Kleine \& von Hauff, 2009) or the model of nested systems as propagated the concept of strong sustainability (Smith \& Farley, 2013). A definition of corporate sustainability should consider the three aspects, systems or dimensions that are an integral part of these models as well as their interdependencies. This is not to say that any aspect or system has a dominant role, nor need all aspects or systems be equally balanced. Although it can be debated that the natural system should enjoy special protection as it cannot be replaced, as posited by advocates of a model of strong sustainability and planetary boundaries. This is an on-going discourse on the level of defining sustainability or sustainable development in general, which is of little help for practitioners looking for guidance on corporate sustainability (Adams, 2006; Haughton \& Hunter, 1994; Málovics, Csigéné, \& Kraus, 2008; Muraca \& Voget-Kleschin, 2011; Neumayer, 2003; Ott, 2003). Linking a value-based definition of corporate sustainability to a general model of sustainability thus leaves companies the freedom to place emphasis on certain aspects or systems if others are not ignored, and the entailing causal feedback loops are considered. As long as the corporate values remain socially functional, the corporation can mature its sustainability values and derived goals and hence develop its corporate sustainability profile with its stakeholders.

\subsection{Corporate Sustainability as Restitutive Act}

Corporate activities use resources. Even when companies are pursuing the ideal of Pareto efficiency, it still implies that resources are depleted over time. As most for-profit companies cause collateral damage in the course of doing business, corporate sustainability should focus on ameliorating this imbalance. Companies that truly want to implement corporate sustainability hence take on responsibility for two goals: (1) The reduction or reversal of detrimental effects that the corporate activities cause and (2) some sort of compensation for the corporate impact on economic, social and natural environments that cannot or would not be reversed. If a company depletes resources and the premise of operation is the continuation of a company's existence, corporate sustainability entails continuously adjusting and optimising its corporate activities. Regarding the more social and environmental aspects, dimensions or systems, corporate sustainability has the objective of maintaining a balance that allows the continuous granting and justification of a company's symbolic or legal licence to operate. Efforts directed to this objective are not an add-on or represent and external element but are integral parts of a company. Corporate activities aligned with this notion of corporate sustainability consider their systemic implications and interdependencies, which is in contrast to Friedman's demand of profit regardless of non-monetary cost (Friedman, 1970). Therefore, any definition of value-based corporate sustainability should aim for some kind of restitution or at least compensation (Figure 2).

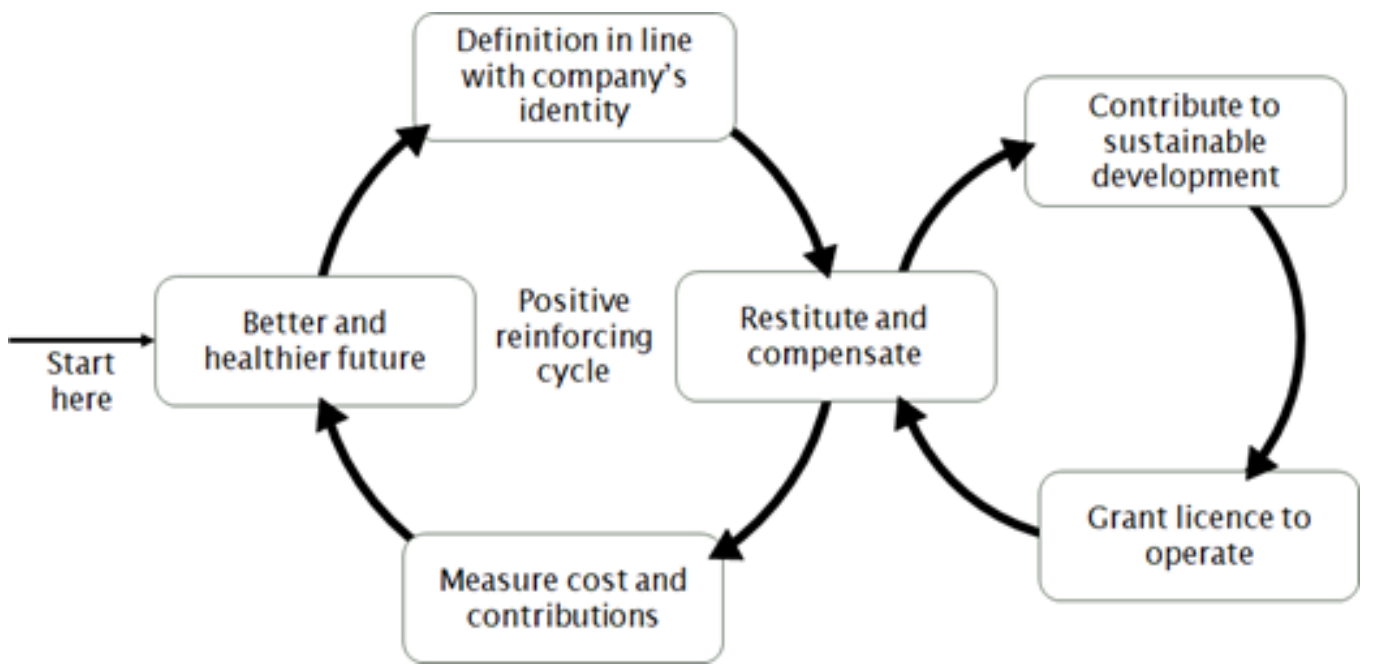

Figure 2. A model of corporate sustainability based on values and aiming at restitutive acts and compensation 


\section{Methods and Empirical Results}

To understand the gap between theory and practice, we analysed how companies deal with the need to base their sustainability efforts on a theoretical foundation. To this avail, 50 websites of companies in Switzerland were screened for a definition of sustainability. The companies were filtered based on a study of environmental goals of companies of the Swiss Federal Office for the Environment (FOEN), carried out in 2016. The first 50 that were highlighted as having specific environmental goals were selected for this study. If any definition could be found, it was categorised. However, if a definition could not be found, the company's general approach to corporate sustainability was analysed to elicit an operational definition used. From this analysis, aspects and elements of a definition of corporate sustainability or an equivalent theoretical basis could be derived.

The results of the empirical analysis confirm that most companies shy from using a clear definition of corporate sustainable (clear definition, $\mathrm{N}=9$ ). Rather, the concept is introduced by an operationalization, either along the lines of the UN's Sustainable Development Goals (SDG), the UN Global Compact, or by complying with GRI reporting or other industry standards, e.g. ISO 14001 or ISO 26000; or the term corporate sustainability is used assuming a general agreement of its definition and significance (no clear definition, $\mathrm{N}=41$ ). Some companies defined their own corporate sustainability, associated guiding principles for sustainability policies and specific targets or themes, however, most demonstrate an understanding of corporate sustainability that does not integrate various perspectives and concerns or is rather tautological: we have existed for a long time and have the intention to operate on long-term perspectives so what we are doing is sustainable and we want to do more of it (Figure 3). Overall, the majority of companies analysed use an explicit or implicit definition of corporate sustainability that is not sufficient to act as a guiding principle for specific corporate sustainability measures (see Table 1).

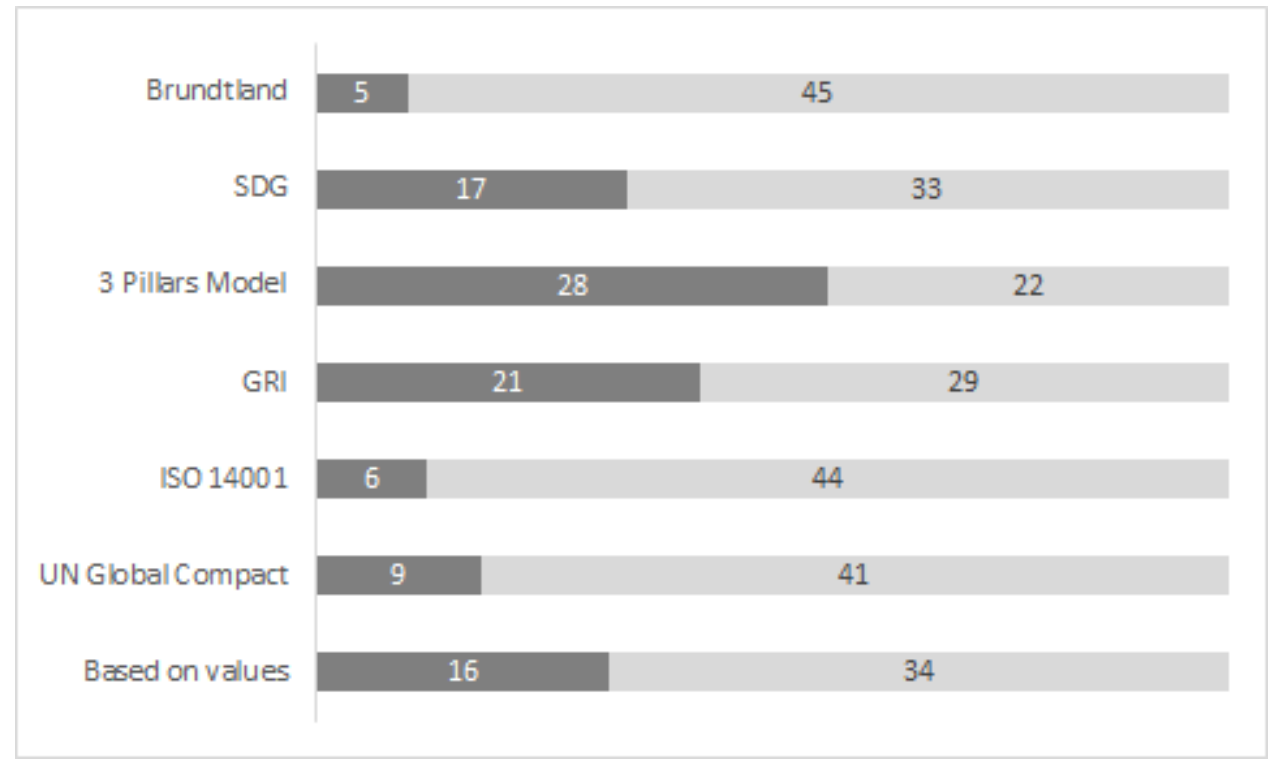

Figure 3. The analysis of websites of Swiss companies show that few use an explicit definition of corporate sustainability, but many refer implicitly to the definition of the Brundtland Commission $(\mathrm{N}=50)$

Although all of the listed standards, goals or frameworks have a topical connection with sustainability in general, most of them are not suitable when it comes to guiding the sustainability efforts of a corporate organisation. The following table (Table 1) provides a short overview of the factors preventing these approaches from successfully addressing corporate sustainability. 
Table 1. Suitability of various approaches to define and guide corporate sustainability used by companies

\begin{tabular}{ll}
\hline Definition & Assessment \\
\hline $\begin{array}{l}\text { Brundtland } \\
\text { Commission }\end{array}$ & $\begin{array}{l}\text { Not suitable for the definition of corporate sustainability as it addresses policy makers } \\
\text { rather than companies }\end{array}$ \\
\hline SDG & $\begin{array}{l}\text { Based on the definition of the Brundtland Commission and addressing the same target } \\
\text { group of policy makers, therefore not suitable for the definition of corporate sustainability }\end{array}$ \\
\hline 3 Pillars Model & $\begin{array}{l}\text { Not sufficient to guide corporate activities as it does not link sustainability efforts to } \\
\text { corporate impact; often exclusively associated with the definition of the Brundtland } \\
\text { Commission and addressing the same target group of policy makers }\end{array}$ \\
\hline GRI & $\begin{array}{l}\text { Reporting standard, therefore not suitable for the definition of corporate sustainability } \\
\text { ISO 14001 }\end{array}$ \\
$\begin{array}{l}\text { Industry standard to formalize management of efforts regarding sustainability but with } \\
\text { suitable for the definition of corporate sustainability }\end{array}$ \\
\hline UN Global Compact & $\begin{array}{l}\text { Too unspecific and risk of whitewashing or other kind of abuse, therefore not suitable for } \\
\text { the definition of corporate sustainability }\end{array}$ \\
\hline Based on values & $\begin{array}{l}\text { In line with the proposed approach, however, to act as guiding principles for sustainability } \\
\text { policies for corporate sustainability efforts, they need to be corporate socially functional }\end{array}$ \\
\hline
\end{tabular}

\section{Discussion and Conclusion}

The aim of this article is to evaluate if and what kind of definition of corporate sustainability companies use and develop an approach that might be more practical in aligning the overall concept of sustainability with concrete sustainability-related corporate activities. When talking to corporate experts, the definition of a sustainable development put forward by the Brundtland Commission is still ubiquitous, although sometimes only implicitly. In more official means of information, e.g. sustainability reports or websites, most companies avoid a clear definition. The UN's definition of sustainable development goals seems to be broadly appreciated by companies. These goals appear in numerous sustainability reports and self-declarations on the internet. The specific description of goals seems to facilitate the compatibility with corporate activities in the field of sustainable development. Also, the different goals prevent internal accounting of sustainability measures and allows false sense of satisfaction with the final results because it suggests a positive outcome, as it is often the case if companies refer to the three pillars model of sustainability. So, companies are more inclined to follow a theoretical path of strong sustainability, and do not regress to weak sustainability with an assumed substitutability of capital. Rather than basing their notion of a sustainable development on more abstract guiding principles, companies adopt the explicit SDG to streamline their sustainability efforts and provide transparency for various stakeholders. Overall, it can be concluded that companies are more willing to accept a norm, standard or ambition for a corporate contribution to a sustainable development if they are presented in a specific form and with limited scope.

Every corporate effort in the field of sustainability should be appreciated. At the same time, a company should meet at least three criteria to be able to claim value-based corporate sustainability efforts: (1) all aspects, dimensions or systems of a general model of sustainability and their interdependencies need to be considered, (2) the resulting initiatives need to demonstrate a direct link to the declared corporate value goals and value issues as well as its value-generating corporate activities, and (3) efforts need to go beyond legal requirements. Other efforts should not be categorised as corporate sustainability but tagged with their specific intentions or goals: 
social, ecological, welfare, supporting local clubs, promoting culture or sports, etc. Corporate sustainability should be characterised by weighing corporate activities against their economic, social and ecological implications and feedback structures with all recipients of their declared corporate values. Corporate sustainability can thus be separated from simple doing something good or charity. Only then does corporate sustainability become something to manage in the sense of "to deal successfully with a problem or difficult situation" (Macmillan Dictionary, n.d.).

Based on the proposed definition, a process of defining corporate sustainability could subsequently look like this (Figure 4): (1) start with the premise the corporate sustainability should aim to make the future a better, healthier place than the present, (2) define and substantiate the corporate goals and the issues addressed by them as well as the current sustainability impacts of the company to gain a licence to operate from the corporation's stakeholders and society in general, (3) reflect on your company's sustainability profile and name the corporate values associated with it, (4) analyse what resources (including abstract or potential, e.g.: time, health, advancement opportunities, tradition, locality, identity, etc.) are affected by your company's activities, and (5) shape your efforts in corporate sustainability to restitute resources that you have affected or compensate in an appropriate, transparent way. The result will be a set of specific sustainability goals that are aligned with your company's identity and values, ready to be communicated to your value recipients, cast into activities and be monitored and reported upon.

\begin{tabular}{|l|l|}
\hline $\begin{array}{l}\text { Premise: The } \\
\text { future is a better, } \\
\text { healthier place } \\
\text { than the present }\end{array}$ & $\begin{array}{l}\text { Licence to operate: } \\
\text { What are the } \\
\text { values, goals and } \\
\text { issues of the } \\
\text { company? }\end{array}$ \\
\hline
\end{tabular}

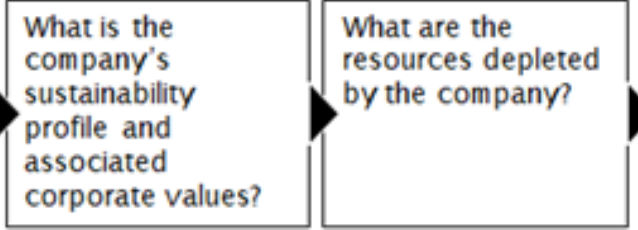

What are the efforts to restitute or compensate?

Figure 4. The process of defining corporate sustainability based on values, with the aim to restitute or compensate

This article provides a thorough theoretical foundation to reject the definition of corporate sustainability solely based on the definition of sustainable development by the Brundtland Commission. Instead, we propose a value-based definition of corporate sustainability that can act as guiding principles for sustainability policies to define activities that aim to restitute and compensate. This delineates a substantial difference to definitions of sustainable development in a socio-political context. Those are often prospective and aim for a better future of a region, nation or society and deal with the long-term shaping of the human existence. It also highlights the difficulties in copying and pasting the original definition of sustainable development of the Brundtland Commission to a corporate context, as the shortcomings are too large to ignore or bridge. The proposed value-based definition of corporate sustainability does not depend on the "needs of the present" or "future generations" and provides a foundation for sustainability goals that is specific for a company and in line with its identity. At the same time, the proposed definition avoids the trap of being too universal and thus generic. By the same token, it does not aim for a general sustainable development as this kind of mandate is not appropriate for companies. As already mentioned by Jennings and Zandbergen (1995), individual companies might contribute to a better and healthier future of a higher-level system of which it is an element, and this higher-level system may in turn be sustainable or not.

A company by and through itself cannot be sustainable. It can only contribute through corporate decisions and aim to increase the level of overall sustainability. The ways and means of these contributions are different for each company and depend on its relevant corporate values. The values guide the company along a desired developmental path and indicate, which of the multitude of options and facets of restitution or compensation are most appropriate, fully acknowledging everything that is deliberately left out. It is this form of corporate sustainability, which reflects and feeds back to its identity and which can shape its uniqueness and provide a background for interacting with stakeholders. If relevant stakeholders can recognise the motivations, goals and means that derive from these corporate values and manifest themselves as corporate sustainability efforts, then support and loyalty can be gained and a company's moral licence to operate will be continued to be granted in the future.

\section{References}

Adams, W. M. (2006). The future of sustainability: Re-thinking environment and development in the twenty-first century. Report of the IUCN renowned thinkers meeting (Vol. 29, p. 31). IUCN. Retrieved from 
http://cmsdata.iucn.org/downloads/iucn_future_of_sustanability.pdf

Bañon Gomis, A. J., Guillén Parra, M., Hoffman, W. M., \& Mcnulty, R. E. (2011). Rethinking the Concept of Sustainability. Business and Society Review, 116, 171-191. https://doi.org/10.1111/j.1467-8594.2011.00381.x

Blewitt, J. (2008). Understanding sustainable development. London; Sterling, VA: Earthscan.

Blewitt, J. (2015). Sustainability: A Dialog of Values. In J. D. B. T.-I. E. of the S. \& B. S. (Second E. Wright (Eds.), International Encyclopedia of the Social \& Behavioral Sciences (2nd ed., pp. 794-800). Oxford: Elsevier. https://doi.org/10.1016/B978-0-08-097086-8.92132-9

Christen, M. (2008). What's the nature of sustainability-conform values? Why a subjective preference approach of values is inadequate in sustainability issues. In Creating values for sustainable development: Proceedings of the 2nd International Sustainability Conference (pp. 18-20). Basel: Gesowip.

Christen, M. (2010). A Theory of the Good for a Conception of Sustainability. In The Sixteenth Annual International Sustainable Development Research Conference (pp. 1-12).

Dow Jones Sustainability Indices. (2014). Corporate Sustainability. Retrieved from http://www.sustainability-indices.com/sustainability-assessment/corporate-sustainability.jsp

Emas, R. (2015). The Concept of Sustainable Development: Definition and Defining Principles. Brieffor GSDR, 1-3. https://doi.org/10.1016/j.marpol.2014.01.019

Frecè, Jan T. (2018). Corporate Values - A Socio-Functionalist Approach Exemplified Along Corporate Sustainability Values (Unpublished doctoral dissertation). University of Basel, Switzerland.

Friedman, M. (1970). The Social Responsibility of Business Is to Increase Its Profits. The New York Times Magazine.

Haughton, G., \& Hunter, C. (1994). Sustainable cities. London; Bristol, Pa.: J. Kingsley Publishers.

Hopwood, B., Mellor, M., \& O'Brien, G. (2005). Sustainable development: mapping different approaches. Sustainable Development, 13(1), 38-52.

Indices, D. J. S. (n.d.). Corporate Sustainability. Retrieved from http://www.sustainability-indices.com/sustainability-assessment/corporate-sustainability.jsp

Jennings, P. D., \& Zandbergen, P. A. (1995). Ecologically Sustainable Organizations: An Institutional Approach. Academy of Management Review. Academy of Management. https://doi.org/10.5465/amr.1995.9512280034

Kanie, N., \& Biermann, F. (2017). Governing through Goals: Sustainable Development Goals as Governance Innovation. The MIT Press.

Keeble, B. R. (1988). The Brundtland report:'Our common future'. Medicine and War, 4(1), 17-25.

Kiss, K. (2011). Rise and Fall of the Concept Sustainability. Journal of Environmental Sustainability, 1(1).

Kleine, A., \& von Hauff, M. (2009). Sustainability-Driven Implementation of Corporate Social Responsibility: Application of the Integrative Sustainability Triangle. Journal of Business Ethics: JBE, 85(3), 517.

Macmillan Dictionary. (n.d.). Retrieved June 5, 2018, from https://www.macmillandictionary.com/dictionary/british/manage

Málovics, G., Csigéné, N. N., \& Kraus, S. (2008). The role of corporate social responsibility in strong sustainability. The Journal of Socio-Economics, 37(3), 907-918.

Marshall, J. D., \& Toffel, M. W. (2005). Framing the elusive concept of sustainability: a sustainability hierarchy. Environmental Science \& Technology, 39(3), 673-682.

Muraca, B., \& Voget-Kleschin, L. (2011). Strong sustainability across culture(s). In G. Banse (Ed.), Sustainable development - The cultural perspective: Concepts - Aspects - Examples (pp. 187-203). Berlin: Edition sigma.

Neumayer, E. (2003). Weak Versus Strong Sustainability: Exploring the Limits of Two Opposing Paradigms. Edward Elgar Publishing.

Norman, W., \& MacDonald, C. (2004). Getting to the Bottom of 'Triple Bottom Line'. Business Ethics Quarterly: The Journal of the Society for Business Ethics, 14(2), 243-262.

Ott, K. (2003). The case for strong sustainability. Greifswald's Environmental Ethics, 59-64. 
Smith, P. A. C., \& Sharicz, C. (2011). The shift needed for sustainability. The Learning Organization, 18(1), $73-$ 86.

Smith, Z. A., \& Farley, H. M. (2013). Sustainability: if it's everything, is it nothing? Routledge.

Stagl, S., \& O'Hara, S. U. (2001). Preferences, needs and sustainability. International Journal of Sustainable Development, 4(1), 4-21.

Stavins, R. N., Wagner, A. F., \& Wagner, G. (2003). Interpreting sustainability in economic terms: dynamic efficiency plus intergenerational equity. Economics Letters, 79(3), 339-343.

United Nations. (2000, September 8). 55/2 United Nations Millennium Declaration. Retrieved May 22, 2018, from http://www.un.org/millennium/declaration/ares552e.htm

United Nations. (2016a). Sustainable development goals. Retrieved June 1, 2018, from https://www.un.org/sustainabledevelopment/sustainable-development-goals/

United Nations. (2016b). Sustainable Development Agenda. Retrieved June 1, 2018, from https://www.un.org/sustainabledevelopment/development-agenda/

van Staveren, I., \& Others. (2012). An Evolutionary Efficiency Alternative to the Notion of Pareto Efficiency. Economic Thought, 1(1, 2012).

World Commission on Environment and Development. (1987). Our common future. Oxford; New York: Oxford University Press.

\section{Copyrights}

Copyright for this article is retained by the author(s), with first publication rights granted to the journal.

This is an open-access article distributed under the terms and conditions of the Creative Commons Attribution license (http://creativecommons.org/licenses/by/4.0/). 